\title{
Management Strategies for Sustainable Beef Cattle Grazing on Forested Rangelands in the Pacific Northwest
}

\author{
Timothy DelCurto, ${ }^{1}$ Marni Porath, ${ }^{2}$ Cory T. Parsons, ${ }^{3}$ \\ and Julie A. Morrison ${ }^{4}$ \\ Authors are ${ }^{1}$ Associate Professor, Department of Animal Sciences, Eastern Oregon Agricultural Research Center, \\ Oregon State University, Union, OR 97883; ${ }^{2}$ Assistant Professor, Department of Rangeland Resources, \\ Malheur County Extension Office, Oregon State University, Ontario, OR 97914; ${ }^{3}$ Assistant Professor, \\ Department of Animal Sciences, Crook County Extension Office, Oregon State University, Prineville, OR 97754; and \\ ${ }^{4}$ Feeder Council Coordinator, Idaho Cattle Association, Boise, ID 83705.
}

\begin{abstract}
Livestock grazing practices on public and private rangelands throughout the western United States are subject to increasing scrutiny. Much criticism arises from the tendency for livestock to concentrate in riparian areas and to disproportionately use the vegetation to the degree that riparian function and vegetation are compromised. The purpose of this synthesis article is to evaluate grazing-management strategies that encourage beef cattle to use forage resources away from riparian areas and areas where topographical features limit grazing use. Specifically, this paper evaluates individual management strategies and attempts to quantify the changes in distribution patterns and vegetation use. An effective strategy uses water development to encourage uniform distribution. Likewise, timing and duration of grazing have dramatic influences on cattle distribution in riparian and upland range areas. In general, early in the grazing season, when upland forage is green and growing, cattle tend to distribute more uniformly than later in the season, when upland vegetation is dormant and cattle disproportionately use riparian areas. In addition, early in the season, cattle grazing forested rangelands seem to prefer south-facing aspects with more open canopies when compared with late-season distribution patterns when concentration switches to northerly aspects, denser canopies, and more diverse diets. Other factors that appear to influence distribution include cow breed, age, and stage of production. In addition, recent research suggests that as cows age, distribution patterns change: Older cows have been reported to travel further from water than their younger contemporaries as long as adequate forage is available in the uplands. Additional research is needed on beef cattle selection, technological applications, efficient herding practices, supplementation strategies, and whole-range management systems that encourage the sustainable use of rangeland resources.
\end{abstract}

\section{Resumen}

En los pastizales públicos y privados del oeste de Estados Unidos las prácticas de apacentamiento están sujetas a un creciente escrutinio. Una gran crítica surge de la tendencia del ganado a concentrarse en las áreas ribereñas y utilizar en forma desproporcionada la vegetación, al grado de que la función ribereña y la vegetación se ven comprometidas. El propósito de este artículo de síntesis es evaluar las estrategias de manejo del apacentamiento del ganado para carne que motivan al ganado a usar los recursos forrajeros fuera de las áreas ribereñas y áreas donde las características topográficas limitan el uso mediante el apacentamiento. Específicamente, este articulo evalúa las estrategias individuales de manejo e intenta cuantificar los cambios en los patrones de distribución y utilización dela vegetación. Una de las estrategias más efectiva es usar aguajes para propiciar una distribución uniforme. Asi mismo, la época y duración del apacentamiento tienen dramáticas influencias en la distribución del ganado relación a las áreas ribereñas y los pastizales de tierras altas. En general, al inicio de la estación de apacentamiento, cuando el forraje en los pastizales de tierras altas esta verde y en una etapa vegetativa, el ganado tiende a distribuirse mas uniformemente en comparación de la distribución obtenida a fines de la estación de apacentamiento cuando la vegetación de las tierras altas esta en dormancia y el ganado tiende a usar en forma desproporcionada las áreas ribereñas. Además, a inicios de la estación de apacentamiento, el ganado apacentando los pastizales boscosos parece preferir la exposición sur con coberturas aéreas más abiertas en comparación con los patrones de distribución a fines de la estación donde la concentración cambia a la exposición norte con coberturas de copa más densas y dietas más diversas. Otros factores que parecen influir en la distribución incluyen el tipo de raza y edad de la vaca y el estado de producción. También la investigación reciente sugiere que conforme la vaca envejece los patrones de distribución cambian en comparación con los patrones mostrados por las vacas jóvenes. Específicamente, se ha reportado que cuando en los terrenos altos hay una disponibilidad adecuada de forraje las vacas viejas viajan mas lejos de los aguajes que las vacas jóvenes. Se necesita investigación adicional respecto a la selección del ganado para carne, aplicaciones tecnológicas y practicas eficientes para mantener los hatos. Estrategias de suplementación y un sistema total de manejo del pastizal que promuevan el uso sostenible de los recursos del pastizal.

Key Words: riparian areas, distribution, mixed-conifer rangelands

Manuscript represents an invited paper for the symposium titled Livestock Grazing Distribution: Impacts on Enterprise and Environmental Sustainability. Paper presented at the 2003 Annual Meeting of the Society for Range Management, Casper, WY.

Correspondence: Timothy DelCurto, Dept of Animal Sciences, Eastern Oregon Agricultural Research Center, Oregon State University, Union, OR 97883. Email tim.delcurto@oregonstate.edu

Manuscript received 23 March 2003; manuscript accepted 15 September 2004. 


\section{INTRODUCTION}

Disproportionately heavy use of riparian areas has been and continues to be a substantial problem on rangelands throughout the western United States. Although some studies have determined that today's rangelands are in better condition than in the past (Busby 1979), others indicate that upland areas have shown greater improvement compared with riparian areas (Platts 1991). Increased soil erosion, greater early spring runoff contributing to a net loss of late-season water-holding capacity, decreased plant and animal biodiversity, decreased productivity of forage species, and poor water quality from reduced sediment filtration and elevated water temperature are some of the critical problems of poor riparian management (CAST 2002). In contrast to drier upland areas, however, riparian zones respond relatively quickly to changes in rangeland management. Research on successful grazing management in riparian areas is a critical need for ranchers and other land managers (Kinch 1989) who are striving to improve these areas.

Historically, grazing management has focused on optimum use of forage from upland areas for maximum livestock production. Research efforts concentrating on wetland and riparian habitats for livestock grazing were limited. As a result, research information on wetland and riparian grazing management is sparse, and information gaps exist regarding sustainable grazing for allotment pastures with both riparian and upland forage resources. Further, proven, beneficial, demonstrative, and costeffective management practices for rangeland grazing in riparian areas are a critical need for ranchers and land managers on both private and public lands.

This article has the following objectives: 1) evaluate management strategies that optimize distribution and forage use of pastures containing riparian and upland areas, and 2) identify needs for additional research regarding optimal distribution and management of beef cattle that graze forested rangelands.

\section{STRATEGIES FOR OPTIMAL DISTRIBUTION}

\section{Timing and Duration of Use}

Timing and duration of grazing are two important factors that must be addressed when designing grazing systems aimed at optimizing livestock distribution and vegetation use patterns across a range site. One such livestock-management strategy may be grazing riparian areas in the spring when key forage species are vegetative, forage quality is high, and ambient air temperatures are low. Duration of grazing may be as important, if not more so, than timing, because of the potential negative impacts on plant longevity associated with regrazing previously grazed vegetation. Regrazing is usually most detrimental to vegetation that is grazed during the early stages of plant growth.

Season of Use. Determination of an appropriate time of year for grazing a specific riparian area is a first step in developing a riparian-grazing approach. Three significant factors when selecting a season of use in any particular riparian area are the predicted responses of plant species, the overall impact on the plant communities, and the soil moisture content on the site. There are, however, advantages and disadvantages to grazing during each season of use.
Early Season (Spring) Grazing. Early season grazing or spring use occurs between early April and mid-July in most of the Pacific Northwest. There is evidence that suggests early season use may be the best management strategy for those situations in which 1) livestock can be attracted to the uplands by succulent, herbaceous forage; 2) cool temperatures discourage cattle from loitering in the riparian areas and, conversely, warmer temperatures in the uplands serve as an attractant to grazing; and 3) well-drained soils reduce the possibility of compaction (Gillen et al. 1985; Clary and Webster 1989; Kinch 1989; Clary and Booth 1993).

One potential advantage of early season grazing of riparian areas is the availability of highly palatable and desirable forages in the uplands, which in turn may give cattle nutritional incentives to leave bottomlands, thereby decreasing vegetation use and possible soil compaction in the riparian areas. The combination of succulent upland forage, cool temperatures, and wet soils near water sources acts to encourage a more dispersed spring grazing pattern (Marlow and Pogacnik 1986; Clary and Booth 1993). Other reasons include the early season availability of upland seeps and springs that provide off-stream watering areas.

Some potential disadvantages of early season grazing exist. First, because of the high soil moisture, riparian areas may be more susceptible to soil compaction, stream bank sloughing, and potential erosion during peak runoff and rainfall. Second, grazing is at the critical growth period of the plants. These plants are using their stored carbohydrates to stimulate both phytomer and leaf growth. Repeat defoliation can deplete the stored carbohydrates and lead to decreased vigor of the plant community. The decreased vigor, in turn, can lead to the invasion of noxious, unpalatable species, reducing the site's grazing potential. Therefore, most grazing strategies that incorporate early use of riparian areas will have early season deferment or nonuse in the rotation-grazing plan in subsequent years.

In a study conducted at the Red Bluffs Experiment station west of Bozeman, Montana, it was reported that stream-bank erosion was the greatest following late June and early July grazing. Although the riparian areas are used less at this time than others, the high moisture content leads to increased soil compaction and stream-bank erosion (Marlow and Pogacnik 1986). Early season grazing also has the potential of uprooting poorly attached plants (Kinch 1989). Therefore, although early season (spring) grazing may be a beneficial strategy to decrease use of riparian areas and increase use of upland forages, the appropriateness of this season for use depends also on soil characteristics that minimize that impact of cattle and, as a result, needs to be determined on a site-specific basis.

Midseason (Summer) Grazing. Midseason or hot-season grazing occurs from mid-July through late September. To prevent riparian area deterioration during midseason grazing, the following should be considered: 1) proper monitoring of grazing animals, along with moderate stocking rate and density; 2) adequate time for vegetation regrowth following defoliation; and 3) proper actions implemented to entice livestock to use the upland forage (i.e. shade and off-stream water sources). Next to season-long grazing, midseason grazing is most detrimental to riparian vegetation health, especially when implemented year after year (Kinch 1989).

Some potential advantages of midseason grazing of riparian areas are decreased soil compaction because of lower soil 
moisture content, adequate moisture content in the soil to allow for regrowth following defoliation, and availability of palatable forage compared with upland sites.

There are numerous potential disadvantages of midseason grazing of riparian areas. The increased maturity of upland vegetation and the increased temperatures both act to drive livestock out of the upland sites and force them to congregate in the cooler riparian areas (Siekert et al. 1985). Because of the available moisture in the riparian areas, the vegetation remains more palatable than upland vegetation, and the livestock will prefer these sites and forages to others. While there, the livestock tend to overgraze the available vegetation, decreasing plant vigor and potential riparian health (Siekert et al. 1985).

Kinch (1989) states that the hot season is the period of greatest stress on the plant community because there is less time for vegetative regrowth and for replenishment of carbohydrate reserves in order to sustain the plant during the dormant period. As the palatability of available herbaceous plants decreases, livestock tend to increase the amount of browsing they do. This could lead to a decrease in the amount of woody species in the riparian area (Kinch 1989). In general, however, limited information exists that quantifies the effects of midseason use on vegetation diversity and the sustainability of the forage resources. Future research is needed that evaluates holistic grazing systems and vegetation responses over extended periods of time.

Midseason (summer) grazing creates a number of challenges to livestock and range managers. Most successful grazing plans call for intensive monitoring of riparian area use and management of the riparian area as a separate pasture. When grazing riparian pastures, summer grazing can maintain or even enhance the riparian vegetation as long as the herbaceous forages remain green and vegetative (Green and Kauffman 1995).

Late-Season (Fall) Grazing. Late-season grazing of riparian areas can be beneficial to riparian vegetation under certain circumstances. During late-season grazing (September through November), the available upland vegetation is most likely very mature and has lower palatability than the green, lush riparian vegetation. To decrease the time that livestock spend in the riparian areas, it is important to provide a source of off-stream water (Porath et al. 2002) and to ensure that there is available off-stream shade for livestock to use to get away from the heat (McIlvain and Shoop 1971).

However, there are some advantages of late-season grazing of riparian areas. The available vegetation has matured and completed its vegetative and reproductive growth cycle, and grazing these plants will not negatively affect them. During the late season, most herbaceous plants have already set seeds, and defoliation will have less impact than from earlier-season grazing. The soil's moisture content is lower, reducing the potential of soil compaction and stream-bank trampling. Given proper temperature and moisture availability in the late cool season, plant growth can provide incentive for livestock to leave the cool riparian areas for more palatable forage in the uplands. Green and Kauffman (1995) found that productivity and the density of riparian meadows were maintained with late-season grazing at moderate levels.

Some potential disadvantages of late-season grazing follow. According to Clary (1999), if weather in the uplands remains hot and dry, cool-season plants will remain dormant, removing the incentive for livestock to leave the cool riparian areas. Continued occupation of the riparian area will lead to overuse of the herbaceous vegetation and use of woody vegetation, which, in turn, can reduce the long-term ability of the vegetation to perform its riparian functions (water absorption, sediment filtration, soil holding abilities etc.). Perhaps the most detrimental aspect of late-season grazing is the impact on shrubs and trees (Clary 1999). During the late summer and fall, cattle preference for woody species usually increases because of these plants' increased protein content and palatability compared with the herbaceous components available (Gillen et al. 1985).

As with any riparian grazing strategy, late-season grazing does not always lead to decreased riparian health. Manoukian (1994) determined that a 4-pasture rest-rotation plan that included late-season use did not reduce tall willow growth or development. Riparian areas in a Bureau of Land Management (BLM) 3-pasture rest-rotation plan on Blucher Creek in southern Wyoming were grazed late every third year and had all age classes of willows, good plant vigor, and predominantly stable stream banks (Kinch 1989).

Winter Grazing. Masters et al. (1996) state that winter use in cold environments may be the least detrimental to riparian health and may even benefit both the range and the riparian conditions by improving livestock distribution and plant response. Winter grazing can be successfully implemented when 1) weather conditions provide frozen ground, which decreases the compaction of soils and the impact on vegetation; 2) offstream water is available, which keeps the livestock from congregating in the stream area; and 3) the pastures are large enough to strategically use supplemental forages and minerals to reduce possible overuse of the stream.

Some potential advantages of winter grazing of riparian areas follow. During winter, it should be the easiest to control the distribution of livestock by proper placement of supplemental water, minerals, and feed. Soil compaction will be dramatically decreased because of the lower soil moisture content and the frozen ground (Severson and Bolt 1978). Grazing of herbaceous plants is not harmful because the plants are dormant at this time and, for most herbaceous vegetation, no growing points are exposed to grazing animals.

Some potential disadvantages of winter grazing follow. Removal of the herbaceous and woody component of a riparian area can dramatically reduce the ability of the area to perform its riparian functions. If spring is wet and water runoff high, the necessary vegetation will not be available to capture sediments or to reduce the energy of the flowing water (Kinch 1989). That will lead to increased sedimentation of the stream and possible increases in erosion and soil loss in the surrounding riparian area. One of the most obvious disadvantages of winter grazing is the potential for decreased performance of the livestock on mature, low-quality forages.

Recent Research. Research conducted at the Eastern Oregon Agricultural Research Center (Union, Oregon) during the summers of 1998 and 1999 (Parsons et al. 2003) focused on the effects of the season of use on livestock distribution patterns and subsequent vegetation use in mountain riparian areas. To quantify the effects of the season of use on beef cattle distribution in relation to the riparian area, 52 cow-calf pairs were 


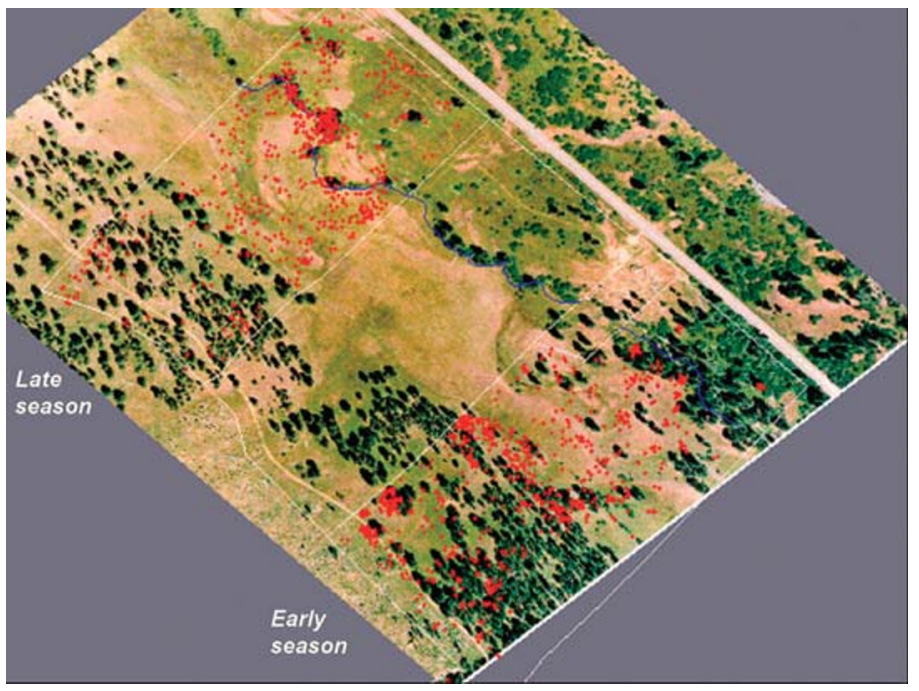

Figure 1. The influence of early season grazing (mid-June to mid-July) versus late-season grazing on beef cattle grazing distribution on forested rangelands. Actual animal locations recorded each hour during a 4-day sampling period. Research conducted at Oregon State University's Hall Ranch (Parsons et al. 2003).

used to evaluate 1) early-summer grazing (mid-June to midJuly) and 2) late-summer grazing (mid-August to mid-September). Within each replication of treatments, cow-calf pairs used during early summer were also used during late-summer grazing periods. Pastures were stocked to achieve $50 \%$ use of herbaceous vegetation after a 28 -day grazing trial. Livestock location and ambient air temperature were recorded hourly during two 4-day periods in each season of use. Locations were transcribed to a geographical information system for the study area. Ocular vegetation-use estimates, forage quality, and fecal deposits within $1 \mathrm{~m}$ of the stream were recorded after grazing. During early summer, cattle were further from the stream $(\mathrm{P}<0.01)$ than in late summer, averaging 161 and $99 \mathrm{~m}$, respectively (Fig. 1). Cows were closer $(\mathrm{P}<0.01)$ to the stream when the ambient air temperatures were higher. Use of riparian vegetation was lower and use of upland vegetation greater during early summer than late summer $(\mathrm{P}<0.05)$. In summary, the season of use affected cattle distribution relative to the riparian area, with late-summer pastures having more concentrated use of the riparian vegetation.

Cattle expressed diurnal distribution patterns in both early summer and late summer $(\mathrm{P}<0.01)$, with cattle farther from the stream in the early morning and, gradually, moving closer to the riparian area as the day progressed. As a result, ambient air temperatures were highly correlated with livestock distances from the stream $\left(\mathrm{r}^{2}=0.79\right.$ and 0.90 in early summer and late summer, respectively; $\mathrm{P}<0.01)$.

Thus, early summer grazing resulted in nearly equal use of upland and riparian vegetation types during both years of the study. In the late-summer grazing period, the green-line vegetation approached $60 \%$, compared with only $36 \%$ use during the early summer, once again showing the increased potential for riparian-area degradation in late summer.

To further evaluate the influence of the season of use on beef cattle distribution and resource use, we decided to use the beef cattle distribution data on the US Department of Agriculture

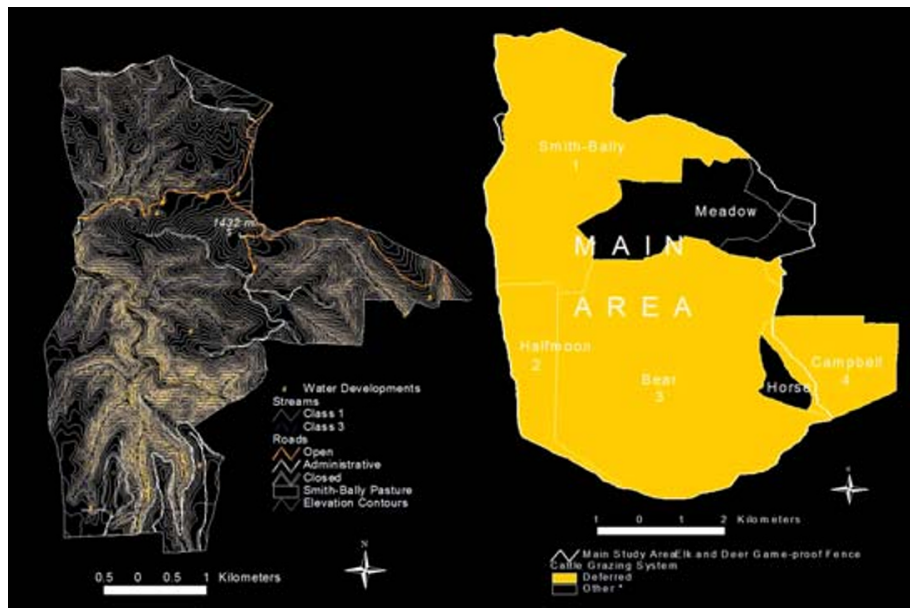

Figure 2. Beef cattle distribution patterns were determined using an automated telemetry system and applied to geographic information system (GIS) images for the Starkey Experimental Forest and Range. The cattle were managed in a deferred rotation system corresponding to the 4 shaded pastures that comprised the main study area (right image). Cattle locations were then evaluated in terms of distance from water and habitat characteristics for the Smith-Bally pasture in early summer grazing (mid-June to late July) in odd years and late-summer grazing (early September to mid-October) in even years. The topographical characteristics of the Smith-Bally pasture are shown on the left.

(USDA), Forest Service, Starkey Experimental Forest (DelCurto et al. 2000). The Experimental Forest has been the site for ongoing research evaluating the interaction of mule deer, elk, and cattle grazed in a deferred-rotation grazing system. The rotational-grazing system involved the use of 4 pastures, with 2 pastures being grazed late or early on an alternate-year basis (Fig. 2). The Smith-Bally pasture (3 $000 \mathrm{ha}$ ) was grazed from mid-June through July during even years and early September through mid-October during odd years. Using radiotelemetry data ( $>52000$ data points) for cattle in this pasture over a 6year period, we evaluated resource selection and landscape use patterns (Fig. 3). In short, early-season grazing by cattle was characterized by distribution patterns being farther from water than the mean pixel average for the pasture. Thus, cattle seemed to prefer areas away from water and showed a strong preference for south-facing aspects and open canopies (Fig. 3). In contrast, during the late season, cattle change their distribution patterns, being closer to water and preferring north-facing aspects and sites with higher forage-production potential. Obviously, both these studies (DelCurto et al. 2000; Parsons et al. 2003) clearly show the influence of the season of use on livestock distribution patterns, landscape use, and, as a result, vegetation use. In addition, late-season grazing on these forested rangelands creates disproportionate use of riparian areas and riparian vegetation. A challenge for land managers is to develop grazing systems and management strategies that mitigate potential damages from late-season use.

\section{Water Developments and Off-stream Water}

A review of the literature clearly shows that cattle distribution is largely determined by the availability of water (Miller and Krueger 1976; Gillen et al. 1985; Pinchak et al. 1991). The 


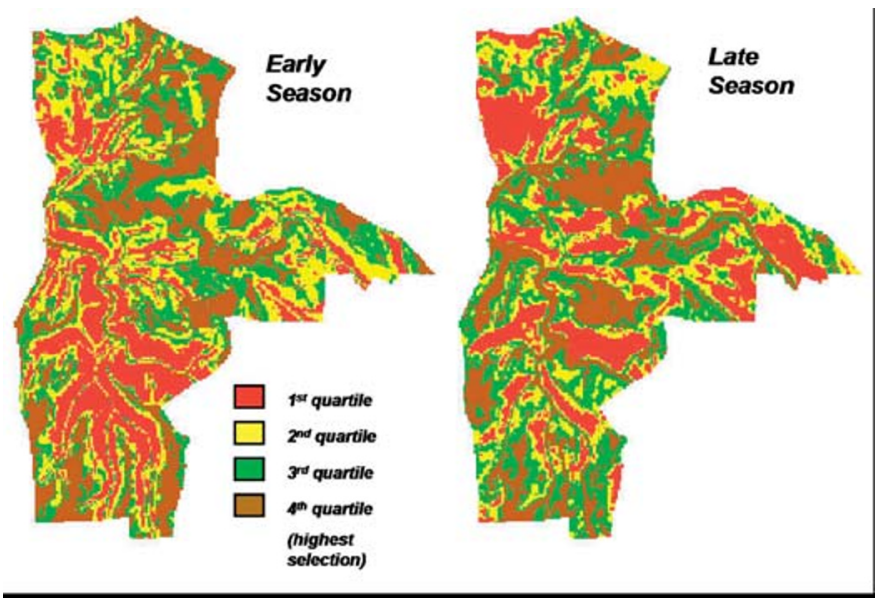

Figure 3. Quartile map of beef cattle distribution patterns on the Smith-Bally pasture of the Starkey Experimental Forest. Distribution patterns were determined using an automated telemetry system and applied to GIS images for the Starkey Experimental Forest and Range. Cattle locations are an average for a 6-year period and reflect early summer grazing (mid-June to late July) in odd years and late summer grazing (early September to mid-October) in even years.

degree to which distribution is influenced by the presence or distribution of water depends on a variety of additional factors that include slope, shade, and vegetation. As reported above, these factors all seem to be interrelated in their effects on grazing distribution, hence creating a need to consider numerous factors when planning and evaluating the use of alternate water as a distribution management tool.

Because water is a critical requirement for cattle, it seems intuitive that the use of off-stream water to alter the distribution of the animals and to decrease riparian grazing pressure is a management strategy that would have positive effects; however, only a few studies have evaluated the quantitative impact of off-stream water on grazing distribution in relation to the stream. Miner et al. (1992) looked at the effects of using an off-stream water source during winter feeding in a riparian meadow to reduce the time cows spent in the stream. During the winter feeding period, cattle responded to the alternative water source by spending less time loafing in the stream. Offstream tanks were most effective during the midday watering bouts with higher water consumption at the off-stream tanks. In a separate study, Godwin and Miner (1996) used an animaloperated pasture pump placed a short distance from the stream to determine the effectiveness of providing an off-stream water source to reduce water-quality impacts. Animals with access to alternate water spent significantly less time at the stream than those with no water trough. This response decreases direct fecal contamination of the stream, because more fecal matter is deposited farther from the stream. It also creates a better opportunity for the riparian vegetation to filter the bacteria, nitrogen, and phosphorus present in the fecal matter.

Previously discussed research dealt primarily with winterfeeding situations or pasture situations in which water was being used a short distance from the stream. To address grazing seasons more typical of public and private rangelands, we initiated a larger-scale study to look at overall distribution changes in relation to the riparian area and adjacent uplands. The objective

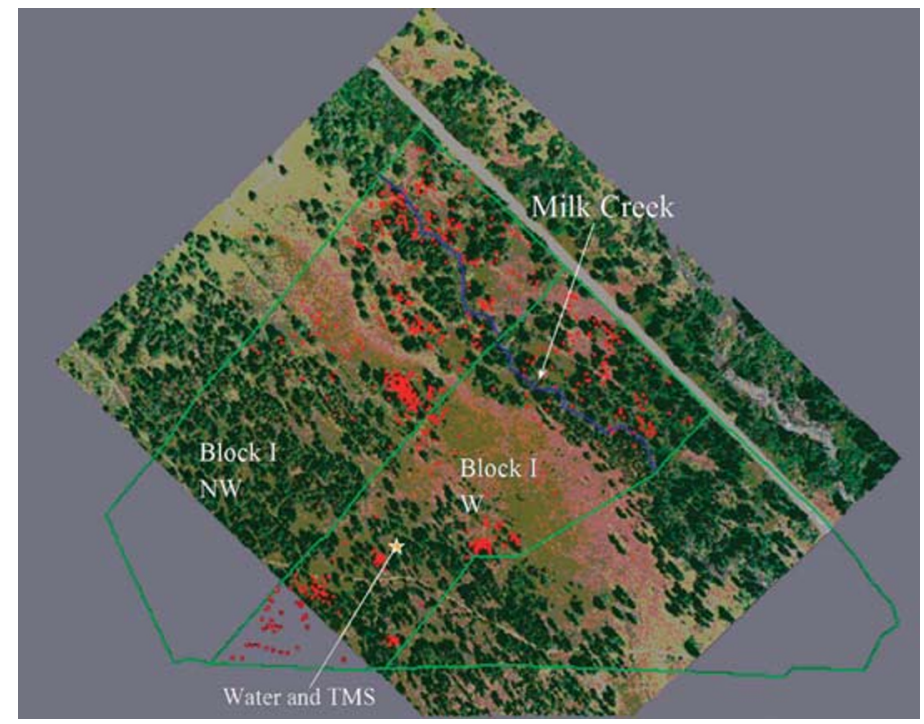

Figure 4. The influence of off-stream water and trace-mineralized salt on distribution patterns of beef cattle grazing forested rangelands with mountain riparian meadows. Animal locations taken every 3 hours over a 6-day observation period and plotted to a geo-corrected aerial photo. Research conducted at Oregon State University's Hall Ranch (Porath et al. 2002).

of this research, conducted at the Hall Ranch at the base of the Wallowa Mountains near Union, Oregon, was to provide a quantitative assessment of the effect of off-stream water and trace-mineral salt on cattle distribution during the summer grazing season in a forested rangeland/riparian meadow setting (Porath et al. 2002). In this study, 2 treatments were compared: 1) grazing without off-stream water or salt (NW) and 2) grazing with off-stream water and trace-mineral (TM) salt to alter distribution (W). Distribution data were collected using visual observations and mapping of cattle locations every 3 hours of daylight during days $14-21$ and $35-42$ of a 42-day grazing period spanning from mid-July to late August (Fig. 4). Visual observations revealed distinct differences in distribution patterns between NW cattle and those with water and TM salt (Fig. 4). Cattle with access to off-stream water displayed a more uniform average distance from the stream throughout the day, whereas cattle without off-stream water or salt began the day farther from the stream $(P<0.05)$, but moved closer to the stream as the day progressed, then moved away again during the early evening hours. Additionally, similar patterns were noted in the early and late observation periods; however, the distribution differences in the early grazing period were more predictable and pronounced than those in the late grazing period. Because pastures were stocked at heavy-use rates, limited forage availability during the last half of the grazing period could have been a driving force in distribution, as cattle were observed grazing less predictably and in areas where they typically did not concentrate throughout the early part of the grazing period. Preand postgrazing shrunk-weights and body condition scores were used to compare cow and calf body-weight change and cowcondition score change between the cattle with access to offstream water and TM and those without. Results showed that cows with access to off-stream water and TM salt gained $11.5 \mathrm{~kg}$ more during the $42 \mathrm{~d}$ grazing period. Calves had 
a similar response, gaining $0.14 \mathrm{~kg} / \mathrm{d}$ more than calves with the stream as their only water source.

Although these results illustrate a clear response of cattle distribution to the presence and distribution of off-stream water and TM salt, they also reinforce the importance of grazing behavior awareness in the development of management plans and the use of management tools. It became clear through observation that cattle began the day with an early morning grazing period lasting until the temperature began to warm. At that time, cattle typically began to search for water. Thus, this particular period of time is crucial in the use of off-stream water as a tool for improved grazing distribution. If the stream is the animals' only water source, they will move to the stream at this time; if there is an alternate water source that is in an appealing place, they will seek that other water source part of the time. Ultimately, the location to which the cattle go for water plays a large role in determining where they loaf and graze during the afternoon hours. However, the success of this and other management strategies can be tied to both the behavioral patterns of the cattle and to the characteristics of the rangeland. Results from this study indicate that off-stream water and trace-mineral salt are most effective in decreasing riparian grazing pressure during the beginning of the rotation when forage is plentiful and during the afternoon hours when temperatures are warmer and water availability is crucial. Finally, as livestock producers and grazing managers search for improved management practices that make grazing increasingly compatible with other natural resource uses, they must consider the underlying factor of economic feasibility. The research at the Hall Ranch showed significant increases in cow and calf weight gains in the group that had access to off-stream water when compared with the group that had the stream as its only water source. As a result, for the conditions of this study, the land manager would have had economic incentives to develop off-stream water because of the improvements in distribution patterns and improvements in cattle performance (Stillings et al. 2003).

\section{Kind or Class, Breed, and Age of Cattle}

In addition to the above strategies for altering livestock distribution, research has also shown that there are inherent characteristics of different kinds or classes, breeds, and ages of livestock that can be used to meet management goals. Following is a brief review of some of these findings, with particular emphasis on research examining the effects of cow age on livestock distribution and use patterns.

Some researchers have shown that modifying the kind or class of animals to find the most suitable livestock for a particular rangeland setting can increase the uniformity of use (Bryant 1982; Bailey et al. 2001). One of the more extreme variations of this strategy involves grazing certain ranges with sheep instead of cattle. May and Davis (1982) suggest that sheep have been shown to exert less influence on some riparian and aquatic ecosystems than cattle. A less drastic example of changing the kind or class of animals to improve distribution involves grazing rangeland with yearling cattle instead of with cow-calf pairs. It has been shown that yearlings can travel farther than cows with young calves (Arnold and Dudzinski 1978), which may ultimately result in more uniform grazing use.
Other research has investigated the influence of cattle breeds on distribution patterns and forage use. Herbel and Nelson (1966) studied the activities of Hereford and Santa Gertrudis cattle on semidesert rangeland in southern New Mexico. The Santa Gertrudis cattle traveled greater distances than the Herefords under the dry, warm conditions. The researchers suggested that these results may have been an effect of the breeding of the Santa Gertrudis Brahman, which could have made them better adapted to the high ambient-air temperatures. Similarly, Bailey et al. (2001) found that Tarentaise and Tarentaise $\times$ Hereford cows would travel farther from water and use steeper slopes than Hereford cows.

Compared with the amount of research on how the kind, class, and breed of livestock can affect grazing patterns, relatively little information is available that specifically addresses the effects of livestock age on distribution across rangelands. Whereas some research has reported that young cattle use rough, timbered terrain more efficiently than older cows (Hedrick et al. 1968), other studies have indicated that mature cows will use steeper slopes, a greater variety of slope classes, and more plant community types than yearling heifers (Bryant 1982). Other work has revealed that 3-year-old cows appear to travel farther from water, both horizontally and vertically, and use higher elevations than 5-year-old and older cows (Bailey et al. 2001). Interestingly, the differences in distribution in that study were observed only during the early part of the grazing season.

On commercial cow-calf operations in the West, livestock operators commonly incorporate first-calf heifers into the main cow herd to graze extensive rangeland pastures. Given the limited and inconclusive research that has been conducted on the effects of cow age on grazing distribution, we designed a 2-year study to specifically compare and quantify the grazing patterns of these two different age classes of cows.

Our study was conducted from late July through early September of 2000 and 2001 in northeastern Oregon (Morrison et al. 2002). The 86 ha used in the study were divided into 4 separate pastures. The plant communities of the area are typical of those found on the mountainous, forested rangelands of northeastern Oregon, eastern Washington, and northern Idaho (Miller and Krueger 1976). Sixty cow-calf pairs each year were stratified by age into the following treatments: 1) 30 first-calf heifers (2 years of age) and 2) 30 mature cows (5, 6, and 7 years of age). Throughout the 2-year study, each pasture was grazed by each treatment group. Cattle were located by hourly visual observations during 4-day periods, both early (days 15-18) and late (days 36-39) in the trial.

Analysis of the visual observation data revealed that during the morning hours of the early observation period, the mature cows distributed farther from the stream $(P<0.10)$ and occupied the riparian-vegetation type less $(P<0.10)$ than first-calf heifers. No differences $(P>0.10)$, however, occurred between the age classes during the rest of the day. Similarly, during the late-season observation period, no differences $(P>0.10)$ in distance from the stream or in time spent in the riparianvegetation type were observed between the age classes. Thus, early in the grazing period, the mature cows did appear to select areas farther from water and to spend more time outside the riparian-vegetation zone than did the first-calf heifers. Limitations in the availability of desirable forage during the latter half of the grazing bout could explain why the distribution 
pattern differences disappeared. As the forage quantity in the initially preferred areas became limiting, both the mature cows and the first-calf heifers appeared to shift their distribution to previously underused areas to maintain their rate of intake. This theory is supported by work done by Senft et al. (1985), which found that at the onset of grazing, cattle foraged in upland areas where preferred species were abundant. The cattle then moved to new areas after depleting the desirable forage on the sites they initially preferred. Although further investigation into the preferences of these different age classes is warranted, our study suggests that better cattle distribution could be achieved by stocking pastures with older, mature cows as long as desirable forage in the uplands is not limiting.

\section{Whole-Ranch Management Strategies}

Sustainable grazing strategies and systems may necessarily involve changes in the overall management of the beef-production unit. Traditional grazing systems have not always incorporated the management needs of the ranch into the overall management plan. In fact, agency management of public lands has been accused of being somewhat inflexible to changes that deviate from traditional allotment management. The traditional animal unit month (AUM) structure has encouraged springcalving beef cattle production with little compensation to producers who calve late or alternative seasons. Likewise, beef cattle producers have not fully evaluated opportunities to help mitigate problems such as disproportionately heavy use of riparian areas on public lands by using private land resources during critical periods such as late summer and early fall.

In the intermountain and interior Pacific Northwest, strategies to reduce heavy usage of riparian areas grazed during late summer to early fall are needed. Alternatives may include early removal of cattle from allotments with late-season distribution and vegetation use problems if alternative pastures are not available. The challenge becomes identifying late-season forage resources and providing incentives for producers to pursue this course of action.

Late-season changes in management may also include the use of early weaning for improved beef cattle distribution. Research is currently ongoing at the Hall Ranch of Oregon State University to evaluate early weaning as a means to mitigate late-season distributional problems. Previous research has suggested that nonlactating cows distribute farther from water and use steeper slopes than lactating cows (Bailey et al., 2001). If early weaning proves to be an effective tool in increasing the use of upland forage and reducing the use of riparian vegetation, specifically woody vegetation, a viable whole-ranch management strategy would include early weaning.

Likewise, additional research is needed to address the effectiveness of late-season supplementation as a tool to improve distribution and vegetation use patterns. Research by Bailey and Welling (1999) has demonstrated that strategic supplementation can be used to effectively change landscape and vegetation use patterns during the fall and winter grazing when the forage is dormant. Additional research is needed that is specific to riparian areas during late summer and early fall. Like early weaning, if late-season supplementation is effective in increasing the use of upland vegetation and subsequent use of riparian vegetation decreases, another tool or strategy may be available.
To fully use supplementation as a distribution management strategy, however, precautions and procedures will need to be implemented to ensure that the supplement cannot be a vector for weed establishment by having seeds of undesirable plants in the supplement and that the supplement is fed in a manner that is not destructive to the range resources.

\section{Old and New Technologies}

The method that has been used the most and is perhaps the least discussed is herding. Herding has been the strategy most often used to discourage the disproportionate use of riparian areas. Moving cattle to areas with available forage or salt placements or away from traditionally overused sites has been a common practice during the past century. Research is currently underway at Montana State University (Bailey and coworkers) that evaluates herding and supplementation as a means to improve distribution patterns on large-scale allotment pastures. It would seem likely that herding could be used more on pastures with distribution problems, providing that the cost of labor is offset by the improvement in use of the allotment pasture. Because of cattle reliance on water sources and the diurnal patterns of cattle movement toward water during the heat of the day, it also seems likely that herding would be most appropriate when coordinated with cattle behavior and alternative water sources.

Another strategy that has been used with success is allotment-pasture design and strategic fencing. Traditional allotments were designed for efficient and sustainable use of upland vegetation. In many cases, the distribution of livestock in relation to water and sensitive riparian areas was not a significant component of the original planning process. With allotment pastures, opportunities to not use sensitive riparian areas need to be explored, particularly during the period when the riparian vegetation and habitat is highly preferred over upland vegetation. Upland pastures with perennial water sources are key to developing these plans. Small riparian areas, such as springs and seeps, are actually more sensitive to grazing impacts than are significant streams. For the springs and smaller areas that provide sources of water, land managers should consider the use of exclusionary fencing and off-site watering tanks. Fencing can be a useful tool for managing livestock distribution and vegetation use. Like all strategies, however, care must be taken to make sure that the strategic fencing is compatible with other multiple-use values for the specific rangeland resource.

In contrast to herding and allotment designs, new technologies may provide tools to influence livestock distribution in the future. Specifically, research evaluating fenceless livestock control using radio frequency and global positioning system (GPS) technology suggests a potential use in influencing livestock distribution and vegetation use. Both GPS and radio frequency approaches involve development of zones available for grazing and areas in which grazing is discouraged. The GPS collar technology uses satellites to locate animals relative to their desired area of grazing (Anderson et al. 2003). In contrast, our research has focused primarily on radio frequency approaches using both ear tags and neck collars. In general, directional radio transmitters are set up to create an area of grazing exclusion (Fig. 5). When cattle fitted with radio receivers move into an exclusion area, their receivers first emit audio warnings followed by electrical shock to encourage movement away 


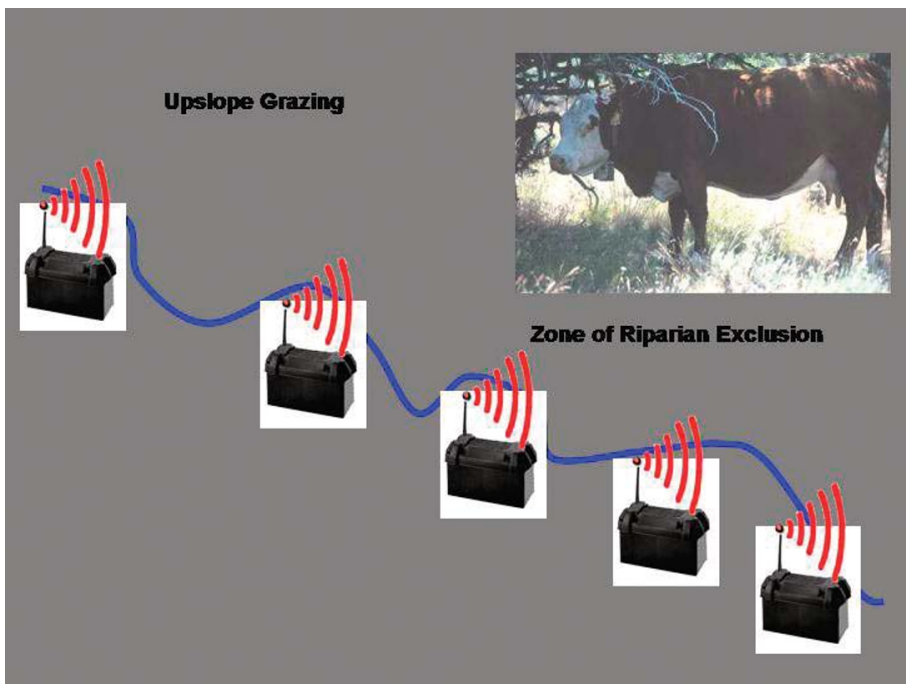

Figure 5. Electronic diversion of livestock involves setting up an exclusion zone established by radio frequency transmitters. Cows are equipped with receivers (ear tags or collars) that, when within the zone, will emit audio followed by electrical stimulus that move cattle out of the area and discourage riparian grazing.

from the area. In general, field tests on both technology applications have been successful in changing livestock distribution patterns. The biggest obstacle to use of this technology will be the development of reliable prototypes that are economic and practical on a large-scale basis. Studies are currently ongoing at Oregon State University (radio frequency) and the USDA Agricultural Research Service (ARS) Jornada Experimental Range (GPS technology) that will further evaluate the usefulness of these technologies and applications to distributional management of livestock on western rangelands.

\section{CONCLUSIONS}

This paper is designed to represent a synthesis of research evaluating strategies to promote uniform grazing distribution of forest rangelands. Strategies or tools to assist the land manager in achieving uniform distribution do exist and, when specifically tailored to a range area, can be effective in promoting sustainable long-term use of public and private range resources. Proper timing and duration of grazing, use of off-stream water, strategic supplementation, herding, proper type and class of animal, and futuristic application of electronic devices may all provide tools to mitigate problems that currently plague livestock and land managers. The use of these strategies matched to forage resources, topographic characteristics, and overall ranch management will be a key ingredient to providing solutions to sustainable grazing on the western rangelands.

\section{LITERATURE CITED}

Anderson, D. M., C. S. Hale, R. Libeau, and B. Nolen. 2003. Managing stocking density in real-time; Proceedings of the VII International Rangeland Congress; 28 July 2003; Durban, South Africa. p. 840-843.

Arnold, G. W., AND M. L. Dudzinski. 1978. Ethology of Free-Ranging Domestic Animals. New York, NY: Elsevier.
Balley, D. W., And G. R. Welling. 1999. Modification of cattle grazing distribution with dehydrated molasses supplement. Journal of Range Management 52: 575-582.

Bailey, D. W., and L. R. Rittenhouse. 1989. Management of cattle distribution. Rangelands 11:159-161.

Balley, D. W., D. D. Kress, D. C. Anderson, D. L. Boss, and E. T. Mlller. 2001 Relationship between terrain use and performance of beef cows grazing foothill rangeland. Journal of Animal Science 79:1883-1891.

Bryant, L. D. 1982. Response of livestock to riparian zone exclusion. Journal of Range Management 35:780-785.

Busby, F. E. 1979. Riparian and stream ecosystems, livestock grazing, and multiple-use management. In: 0. B. Cope [ed.]. Proceedings of the forum: Grazing and riparian/stream ecosystems; 3-4 November 1978; Denver, C0. Vienna, VA: Trout Unlimited. p 6-12

[CAST] Council for Agricultural Science and Technology. 2002. Issue paper: Environmental impacts of livestock on US grazing lands. W. C. Kruger and M. A. Sanderson (cochairs). Paper No. 22: p 1-16.

CLARY, W. P. 1999. Stream channel and vegetation responses to late spring cattle grazing. Journal of Range Management 52:218-227.

Clary, W. P., and B. F. Webster. 1989. Managing grazing of riparian areas in the Intermountain Region. Ogden, UT: USDA Forest Service Research. Paper INT+263.

ClaRY, W. P., AND G. D. Booth. 1993. Early season utilization of mountain meadow riparian pastures. Journal of Range Management 46:493-497.

DelCurto, T., B. Johnson, M. Vavra, A. A. Agars, and P. K. Coe. 2000. The influence of season of use on distribution patterns relative to water and resource use by beef cattle grazing mixed forested rangelands. Proceedings of the Western Section of the American Society for Animal Science; 21-24 June 2000; Davis, CA; 51:171-175.

Gilllen, R. L., W. C. Krueger, and R. F. Miller. 1985. Cattle use of riparian meadows in the Blue Mountains of northeastern Oregon. Journal of Range Management 38:205-209.

Green, D. M., And J. B. Kauffman. 1995. Succession and livestock grazing in a northeastern Oregon riparian ecosystem. Journal Range Management 48(4):307-313.

Godwin, D. C., AND J. R. Miner. 1996. The potential of off-stream livestock watering to reduce water quality impacts. Bioresource Technology 58:285-290.

Herbel, C. H., and A. B. Nelson. 1966. Activities of Hereford and Santa Gertrudis cattle on a southern New Mexico range. Journal of Range Management 19: 173-181.

Hedrick, D. W., J. A. Young, J. A. B. McArthur, and R. F. Keniston. 1968. Effects of forest grazing practices on mixed coniferous forests of northeastern Oregon. Corvallis, OR: Oregon Agricultural Experimental Station. Technical Bulletin 103. $24 \mathrm{p}$

KINCH, G. 1989. Riparian area management, grazing management in riparian areas. Denver, C0: US Department of the Interior, Bureau of Land Management. Technical Reference 1734-4.

Manoukian, M. E. 1994. Evaluation of tall willows (Salix spp.) within a livestock grazing allotment in southwest Montana. [thesis], Montana State University, Bozeman, MT.

Marlow, C. B., and T. M. Pogacnik. 1986. Cattle feeding and resting patterns in a foothills riparian zone. Journal of Range Management 36:212-217.

Masters, L., S. Swanson, And W. BuRKhaRdt. 1996. Riparian grazing management that worked: I. Introduction and winter grazing. Rangelands 18(5):192-195.

May, B., AND B. Davis. 1982. Practices for livestock grazing and aquatic habitat protection on western rangelands. In: Wildlife-Livestock Relationships Symposium: Proceedings of the 10th University of Idaho Forest, Wildlife, and Range. Moscow, ID: Experimental Station. p 271-278.

Mclıvain, E. H., AND M. C. Shoop. 1971. Shade for improving cattle gains and rangeland use. Journal of Range Management 24:181-184.

Milleer, R. F., AND W. C. Krueger. 1976. Cattle use on summer foothill rangelands in northeastern Oregon. Journal of Range Management 29:367-371.

Miner, J. R., J. C. Buckhouse, AND J. A. Moore. 1992. Will a water trough reduce the amount of time hay-fed livestock spend in the stream (and therefore improve water quality)? Rangelands 14(1):35-38. 
Morrison, J. A., T. DelCurto, C. T. Parsons, G. D. Pulsipher, K. Walburger, M. Wells, and E. S. Vanzant. 2002. The influence of cow age on grazing distribution and utilization of mountain riparian areas and adjacent uplands. Proceedings of the Western Section of the American Society for Animal Science; 19-21 June 2002; Fort Collins, C0; 53:53-57.

Parsons, C. T., P. A. Momont, T. DelCurto, M. Mclnnis, and M. L. Porath. 2003. Cattle distribution patterns and vegetation use in mountain riparian areas. Journal of Range Management 56:334-341.

Pinchak, W. E., M. A. Smith, R. H. Hart, and J. W. Waggoner, JR. 1991. Beef cattle distribution patterns on foothill range. Journal of Range Management 44: 267-275.

PlatTs, W. S. 1991. Livestock grazing. In: Influences of forest and rangeland management on salmonid fishes and their habitats. Bethesda, MD: US Department of Agriculture, Forest Service. Publication 19.

Porath, M. L., P. A. Momont, T. DelCurto, N. R. Rimbey, J. A. Tanaka, and M. Mclnnis. 2002. Off-stream water and trace mineral salt as management strategies for improved cattle distribution. Journal of Animal Science 80:346-356.
Senft, R. L., L. R. Rittenhouse, and R. G. Woodmansee. 1985. Factors influencing patterns of cattle grazing behavior on shortgrass steppe. Journal of Range Management 38:82-87.

Severson, K. E., and C. E. Bolt. 1978. Cattle, wildlife, and riparian habitats in the western Dakotas. In: Management and use of northern plans rangeland. Regional Rangeland Symposium. 27-28 February; Bismarck, ND; p 90-103.

Siekert, R. E., Q. D. Skinner, M. A. Smith, J. L. Dodd, and J. D. Rodgers. 1985. Channel response of an ephemeral stream in Wyoming to selected grazing treatments. In: Riparian ecosystems and their management: Reconciling conflicting uses. R. R. Johnson, D. D. Ziebell, D. R. Patton, P. F. Patton, P. F. Folliott, and R. H. Hamre [tech. coords.] First North American Riparian Conference; 16-18 April; Tucson, AZ. Ft. Collins, CO: USDA Forest Service. General Technical Report RM-120. p 276-278.

Stillings, A. M., J. A. Tanaka, N. R. Rimbey, T. DelCurto, P. A. Momont, and M. L. PoRATH. 2003. Economic implications of off-stream water developments to improve riparian grazing. Journal of Range Management 56:418-424. 